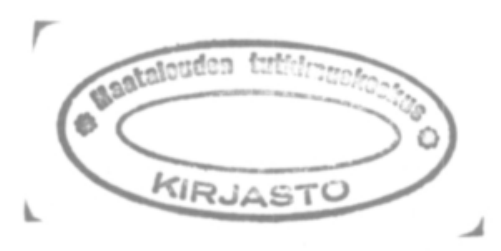

\title{
CARBOHYDRATE AND ACID COMPOSITION OF SOME APPLE VARIETIES
}

\author{
Majja-Litsa SAlo and Irmeli Korhonen \\ Department of Animal Husbandry, University of Helsinki
}

Received January 26, 1972

\begin{abstract}
Sugars, starch, hemicellulose polysaccharides, cellulose, crude lignin, titratable and total acidity and organic salts, crude protein and ash in five Finnish-grown and four imported apple varieties were determined. The main group of apple flesh proved to be sugar, 65-80 per cent of dry matter. Starch occurred only in negligible amounts. Hemicellulose accounted for 7-11 per cent, and almost all of it belonged to the pectin group. Xylan, cellulose and lignin together accounted for $4.5-6$ per cent. The total of plant acids in the Finnish varieties was nearly 7 per cent. In the foreign varieties it was much lower. $20-35$ per cent of the acids were in the form of salts. The titratable acidity was 5580 per cent of the total acidity.
\end{abstract}

The composition of apples has been the subject of many studies in most of which, however, only few chemical constituents have been determined. KENWORTHY and Harris (1963) made an extensive investigation into the composition of three varieties of apples as related to environment and season. Wilkinson $(1957,1958)$ studied the effect of orchard factors on the mineral and titratable acid composition of apples. Kvåle (1963, 1969) and LJONEs and LANDFALD (1966) investigated the composition of apples grown under different environmental conditions in Norway. All these authors determined the titratable acidity, most of them also the sugars, and one author the various pectin fractions.

In the present study the composition of apples commercially available in Finland was investigated. Five domestic and four imported varieties were studied. The study was associated with a study of berries (SAlo \& Suomi 1972), and the determinations made were the same: sugars, starch, hemicellulose, cellulose, lignin, titratable and total acidity, organic salts, crude protein, and ash. The purpose was to compare the composition of apple and berries, and at the same time to discover the difference between apple varieties.

\section{Materials and methods}

M a t e ri a ls. Seven apple samples were obtained from Helsinki vegetable market or from food stores, while Akerö and Wealthy were grown in the garden of the Viik Experimental Farm. The Transparente blanche and Sävstaholm were obtained in September, the other Finnish-grown apples in October, and all imported varieties in the 
beginning of December. The criterion of the ripeness of Finnish apples was that the seeds were brown.

Each sample consisted of 8-10 apples. They were peeled, the core was removed, and the fruit was cut into slices, and dried in a vacuum oven at $40^{\circ} \mathrm{C}$. The dry sample was ground in an IKA analysis mill.

$\mathrm{Methods}$. The methods were those described in connection with the study of berries (Salo 1965, Salo \& Kotilainen 1969, Salo \& Suomi 1972). For carbohydrates, however, also a determination of starch was found necessary. Since the apple, like berries, was assumed to contain water-soluble polysaccharides of the hemicellulose group, the hemicellulose was determined directly from ethanol-extracted residue which includes starch. The starch was determined from a separate sample by the method of SALO and SAlmi (1968), and the result was subtracted from the group hemicellulose + starch.

\section{Results and discussion}

Carbohydrates. Table 1 presents the carbohydrate contents of the apples. The results reveal that the predominant constituent is sugar which, as in berries, is mostly in a monosaccharide form. The apples also contain some starch, most varieties show only negligible amounts but two domestic varieties have a somewhat higher starch content. The difference in the starch content could also be seen by microscope.

Table 1. Carbohydrate and lignin contents of apple flesh, percentages of dry matter.

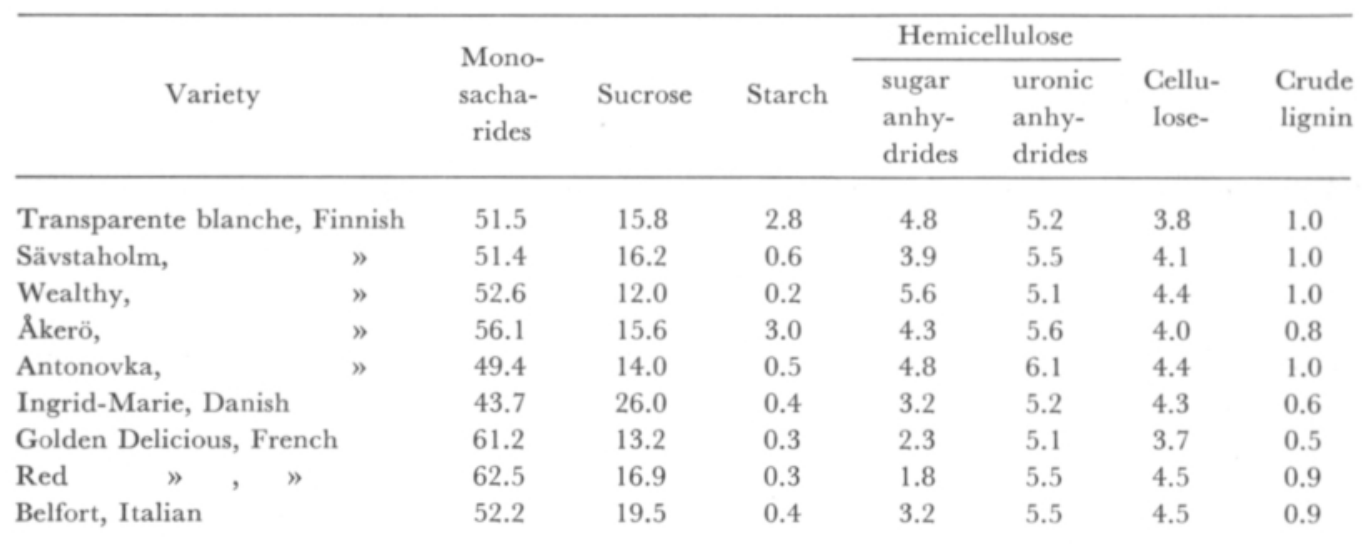

The hemicellulose of the apples is mostly pectin, as can be concluded from the fact that it consists almost exclusively of uronic acids, galactose and arabinose. Xylose, a sugar unit of vascular bundles, accounts for only about 0.5 per cent of the dry matter. The composition of hemicellulose was investigated by paper chromatography, but the results are not entered in the tables since the hemicellulose content in apples is low.

As regards carbohydrates, the information found in the literature is limited to sugars and pectin. LJONEs and LANDFAld (1966) and KvÅLe (1969) have reported from Norway sugar contents of the order obtained in the present study. According to Kvåle both enviromental factors and variety affect the sugar content. KENwOrTHY and Harris (1963) 
analysed three varieties two of which (Red Delicious and Golden Delicious) are included also in the present study. The sugar contents they reported are, however, erroneously high: when the results are calculated on dry matter, the sugar content of one-third of the samples exceeds 100 per cent. - Many authors pay too little attention to the analytical methods, and their papers state laconically that a modification of some method was used.

The pectin content, found by KENWORTHY and HARRIs (1963) by solution-precipitation method, agrees relatively well with the hemicellulose content obtained in the present study. The variation range in their studies is, however, much greater.

Table 2. Free and combined plant acids of apples per $1 \mathrm{~g}$ dry matter.

\begin{tabular}{|c|c|c|c|c|c|c|c|c|c|c|}
\hline & \multicolumn{2}{|c|}{$\begin{array}{l}\text { Acidity, } \\
\text { mequiv. }\end{array}$} & \multirow{3}{*}{$\begin{array}{l}\text { Correct- } \\
\text { ions }^{1} \text { ) } \\
\text { mequiv. }\end{array}$} & \multicolumn{2}{|c|}{$\begin{array}{l}\text { Corrected total } \\
\text { acidity }\end{array}$} & \multirow{3}{*}{$\begin{array}{c}\text { Water.-sol. } \\
\text { cations, }^{2} \text { ) } \\
\text { mequiv. }\end{array}$} & \multirow{2}{*}{\multicolumn{2}{|c|}{$\begin{array}{c}\text { Plant } \\
\text { acids } \\
\text { mequiv. }\end{array}$}} & \multirow{3}{*}{$\begin{array}{l}\text { Free } \\
\text { acids } \\
\% \text { of } \\
\text { total }\end{array}$} & \multirow{3}{*}{$\begin{array}{c}\text { Titra- } \\
\text { table } \\
\text { acidity } \\
\% \text { of total }\end{array}$} \\
\hline & titra- & & & & as malic & & & & & \\
\hline & table & total & & & $\operatorname{acid} \%$ & & free & salts & & \\
\hline Transparente blanche & 0.83 & 1.09 & 0.05 & 1.04 & 7.0 & 0.25 & 0.84 & 0.20 & 81 & 76 \\
\hline Sävstaholm & 0.79 & 1.05 & 0.03 & 1.02 & 6.8 & 0.28 & 0.77 & 0.25 & 75 & 75 \\
\hline Wealthy & 0.84 & 1.04 & 0.03 & 1.01 & 6.8 & 0.27 & 0.77 & 0.24 & 76 & 81 \\
\hline Åkerö & 0.65 & 0.90 & 0.04 & 0.86 & 5.8 & 0.26 & 0.64 & 0.22 & 74 & 72 \\
\hline Antonovka & 0.82 & 1.02 & 0.02 & 1.00 & 6.7 & 0.23 & 0.79 & 0.21 & 79 & 80 \\
\hline Ingrid-Marie & 0.53 & 0.79 & 0.04 & 0.75 & 5.0 & 0.24 & 0.55 & 0.20 & 73 & 67 \\
\hline Golden Celicious & 0.26 & 0.48 & 0.02 & 0.46 & 3.1 & 0.19 & 0.29 & 0.17 & 63 & 54 \\
\hline Red $\quad "$ & 0.19 & 0.34 & 0.02 & 0.32 & 2.1 & 0.13 & 0.21 & 0.11 & 66 & 56 \\
\hline Belfort & 0.36 & 0.53 & 0.03 & 0.50 & 3.4 & 0.21 & 0.32 & 0.18 & 64 & 68 \\
\hline
\end{tabular}

1) Corrections for $\mathrm{PO}_{4}{ }^{3-}$ and $\mathrm{Cl}^{-}$.

2) See text.

$\mathrm{Plant}$ acids and their salts. Table 2 presents the results concerning organic acid and salts. It is noted that the acid content in apples is considerably lower than in berries (SAlo \& Suomi 1972). The equivalents were calculated as malic acid since this is the predominant acid in apples (KvÅLE 1969). A difference can be seen between Finnish-grown and imported apples. In most Finnish-grown apples, the total acidity is nearly 7 per cent of the dry matter, whereas the French and Italian varieties contain only one-third to half that amount, and the Danish variety is in-between. The longer storage of imported apples may account for the difference. Vesterheim (1970) found that titratable acidity fell from September to December by some 30 per cent. This explains, however, only a part of the difference. Variety characteristics doubtless also play a part, for Kenworthy and Harris (1963) also reported almost as low titratable acidity contents for the Red Delicious and Golden Delicious as those found in the present study. On the other hand, Norwegian authors reported titratable acid contents equal to or slightly higher than those found in the present study, and figures of the same magnitude were also published by Wilkinson $(1957,1958)$ from England. Either the varieties grown on the more northerly latitudes are richer in acid or the colder climate enhances this characteristic. The same finding was made concerning the Finnish and Hungarian raspberry (SAlo \& Suomi 1972). 
Water-soluble potassium, sodium, calcium and magnesium were determined for the determinations of organic salts, but only their sum is presented. The sum is composed mostly of potassium.

Table 2 shows that about $20-35$ per cent of the acids occurs in the form of salts, a slightly higher proportion than in berries. The quantity of free acids does not agree with the titratable acidity as well as it did for berries, yet much better than in leaf material (SAlo \& Kotilainen 1969). No results concerning total acids and the share of organic salts were found in the literature.

Table 3. Dry matter content and the main groups of dry matter of apple flesh.

\begin{tabular}{|c|c|c|c|c|c|c|c|c|c|}
\hline \multirow[b]{2}{*}{ Variety } & \multirow[b]{2}{*}{$\begin{array}{l}\text { Dry } \\
\text { matter }\end{array}$} & \multicolumn{7}{|c|}{ Percentages of dry matter } & \multirow[b]{2}{*}{$\begin{array}{l}\text { Ratio } \\
\text { sugar/ } \\
\text { acid }\end{array}$} \\
\hline & & Sugars & $\begin{array}{c}\text { Other } \\
\text { carbo- } \\
\text { hydrates }\end{array}$ & $\begin{array}{l}\text { Crude } \\
\text { lignin }\end{array}$ & $\begin{array}{l}\text { Plant } \\
\text { acids }\end{array}$ & Protein & Ash & $\begin{array}{c}\text { Total } \\
\text { determined }\end{array}$ & \\
\hline Transparente blanche & 15.1 & 67.3 & 16.6 & 1.0 & 7.0 & 1.6 & 1.8 & 95.3 & 9.6 \\
\hline Sävstaholm & 14.9 & 67.6 & 14.1 & 1.0 & 6.8 & 1.2 & 1.9 & 92.6 & 9.9 \\
\hline Wealthy & 13.2 & 64.6 & 15.3 & 1.0 & 6.8 & 1.8 & 1.5 & 91.0 & 9.5 \\
\hline Åkerö & 13.6 & 71.7 & 16.9 & 0.8 & 5.8 & 1.9 & 1.9 & 99.0 & 12.4 \\
\hline Antonovka & 15.1 & 63.4 & 15.8 & 1.0 & 6.7 & 2.0 & 1.7 & 90.6 & 9.5 \\
\hline Ingrid-Marie & 13.9 & 69.7 & 13.1 & 0.6 & 5.0 & 1.9 & 1.8 & 92.1 & 13.9 \\
\hline Golden Delicious & 12.7 & 74.4 & 11.4 & 0.5 & 3.1 & 1.6 & 1.3 & 92.3 & 24.0 \\
\hline Red $\quad "$ & 15.2 & 79.4 & 12.1 & 0.9 & 2.1 & 1.5 & 1.2 & 97.2 & 37.8 \\
\hline Belfort & 15.8 & 71.7 & 13.6 & 0.9 & 3.4 & 1.5 & 1.2 & 92.3 & 21.1 \\
\hline
\end{tabular}

Table 3 is a combination of the analysis results classified into main groups. It shows clearer than the earlier tables that the domestic varieties contain more cell-wall polysaccharides and organic acids and less sugars than the foreign varieties. The sugar/acid ratio is markedly different.

\section{REFERENCES}

Kenworthy, A. L. \& Harris, N. 1963. Composition of McIntosh, Red Delicious and Golden Delicious apples as related to environment and season. Michigan State Univ. Quart. Bull. 46:293-334.

KvÅLE, A. 1963. Kan fruktkvalitet maelast? Frukt og Baer 16:34 -40 .

- - 1969. Chemical composition of apples grown at different altitudes in the Sørfjord, Hardanger. Acta Agr. Scand. 19:3-10.

LJones, B. \& LANDFAld, R. 1966. Composition and quality of Gravenstein apples grown under different enviroments in Norway. Meld. Norges landbr. høgsk. 45:1-20.

SALo, M.-L. 1965. Determination oî carbohydrate fractions in animal foods and faeces. Acta Agr. Fenn. 105:1-102.

SAlo, M.-L. \& SAlmi, M. 1968. Determination of starch by the amyloglucosidase method. J. Sci. Agric. Soc. Finl. 40:38-45.

Salo, M.-L. \& Kotilainen, K. 1969. Determination of free and combined plant acids. J. Sci. Agric. Soc. Finl. 41:277-289. 
Salo, M.-L. \& Suom, K. 1972. Carbohydrate and acid composition of Finnish berries. J. Sci. Agric. Soc. Finl. 44:68-75.

Vesterheim, S. 1970. Verknader av haustetid på kvalitet og lagringseigenskapar hos eple. Meld. Norges landbr. hogsk. 49:1-19.

WiLkinson, B. G. 1957. The effect of orchard factors on the chemical composition of apples. I. Some effects of manurial treatment and of grass. J. hort. Sci. 32:74-84.

Wilkinson, B. G. 1958. II. The relationship between potassium and titratable acidity, and between potassium and magnesium, in the fruit. J. hort. Sci. 33:49-57.

\title{
SELOSTUS
}

\section{SUOMESSA KAUPAN OLEVIEN OMENIEN HIILIHYDRAATTI- JA HAPPOPITOISUUDESTA}

\author{
Maija-Litsa Salo ja Irmeli Korhonen \\ Kotieläintieteen laitos, Helsingin yliopisto
}

Tutkimuksessä määritettiin viidestä kotimaisesta ja neljästä ulkomaisesta omenalajikkeesta sokerit, tärkkelys, hemiselluloosahiilihydraatit, selluloosa, raakaligniini, vapaana ja suolamuodossa olevat kasvihapot, raakaproteiini ja tuhka.

Yleispiirteenä todettiin, että omenien malto-osan kuiva-aineesta pääosa eli $65-80 \%$ on sokeria. Tärkkelystä on hyvin vähän. Hemiselluloosaa on $7-11 \%$ ja se on melkein kokonaisuudessaan ns. pektiiniä. Vaikealiukoista kettoainetta eli ksylaania, selluloosaa ja ligniiniä on yhteensä $4.5-6 \%$. Kasvihappojen kokonaismäärä on suomalaisissa lajikkeissa lähes $7 \%$ kuiva-aineesta, ulkomaisissa paljon alempi. $20-35 \%$ hapoista on suolamuodossa. 